\title{
Sample size in studies on the germination process
}

\begin{tabular}{|r|l|}
\hline Journal: & Botany \\
\hline Manuscript ID & cjb-2015-0161.R1 \\
\hline Manuscript Type: & Article \\
\hline Date Submitted by the Author: & $10-$-Nov-2015 \\
\hline Complete List of Authors: & $\begin{array}{l}\text { Ribeiro-Oliveira, João Paulo; Universidade Federal de Uberlândia, Instituto } \\
\text { de Ciências Agrárias; Universidade Federal do Acre, Centro de Ciências } \\
\text { Biológicas e da Natureza } \\
\text { Ranal, Marli; Universidade Federal de Uberlândia, Instituto de Biologia }\end{array}$ \\
\hline Keyword: & $\begin{array}{l}\text { Cerrado species, diaspore physiological quality, germination } \\
\text { measurements, seed testing }\end{array}$ \\
\hline
\end{tabular}

SCHOLARONE ${ }^{m}$

Manuscripts 


\title{
Sample size in studies on the germination process
}

\author{
João Paulo Ribeiro-Oliveira ${ }^{1, *}$; Marli A. Ranal ${ }^{2}$ \\ ${ }^{1}$ Instituto de Ciências Agrárias, Universidade Federal de Uberlândia. Avenida João Naves de \\ Ávila, 2121, 38400-902, Uberlândia, MG, Brazil. Phone/Fax: (55) 34 3218-2225. \\ * Corresponding author (e-mail: ribeirooliveirajp@gmail.com) \\ ${ }^{2}$ Instituto de Biologia, Universidade Federal de Uberlândia. Avenida João Naves de Ávila, \\ 2121, 38400-902, Uberlândia, MG, Brazil. Phone/Fax: (55) 34 3218-2225
}




\begin{abstract}
Studies on diaspore germination in native species with low economic relevance and great ecological significance have been based on a wide range of sample sizes. However, can the sample size change the physiological inferences made from germination measurements? To answer this question, diaspores of six Cerrado species were evaluated for germinability, germination time (initial, mean, and final), germination velocity (mean germination rate and Maguire's rate), coefficient of variation of the germination time, and synchronization index of the germination process. Germinability, final time, mean time, and synchronization index were robust with respect to sample size fluctuation. Maguire's rate, initial time, coefficient of variation of the germination time and mean germination rate, in contrast, were affected by sample size fluctuation, at least in one of the species tested. The robustness of the time measurements and the synchronization index also demonstrates that the germination process occurs in a cadenced rhythm, much like a biological clock. Among the measurements evaluated, Maguire's rate is the only one that must be avoided, since it is strongly influenced by sample size and by the balance between germinability and mean germination rate. These results demonstrate that sample size can affect inferences about the germination process and can compromise restoration and/or conservation efforts.
\end{abstract}

Keywords: Cerrado species, diaspore physiological quality, germination measurements, seed testing. 


\section{Introduction}

Understanding diaspore germination is important in forest management, since it is one of the bases for restoration and/or conservation projects (Guariguata and Pinard 1998; Guariguata 2000; Freitas and Pinard 2008; Ferreira et al. 2015). Furthermore, germination can segregate species and individuals into groups, demonstrating its potential for use in native species genetic improvement programs (Ferreira et al. 2015). To measure this process more accurately, researchers have proposed mathematical expressions to quantify the synchronicity, uniformity, and velocity of germination (Ranal and Santana 2006; McNair et al. 2012). Some of these measurements have been used during the last two centuries (Ranal and Santana 2006), but intensely discussed and employed in germination studies only in the last decade. During this decade, reviews have been published demonstrating how to calculate and interpret these measurements (see more in Ranal and Santana 2006; Ranal et al. 2009; McNair et al. 2012), making them more accessible to the general public.

Although very informative, those reviews do not address the robustness (hardiness) of the germination measurements used to infer the physiological quality of a diaspore sample in relation to fluctuations in the sample size (the number of diaspores that represents a population in a treatment). This sample size fluctuation is common in studies on native species that possess lower economic relevance, but still have great ecological significance. Most of these species, unlike domesticated ones, have ecological reproductive difficulties such as seasonal production, theft of pollen and herbivory or predation of diaspores (Guariguata and Pinard 1998; Ferreras and Galetto 2010; D'hondt and Hoffman 2011; Sobral et al. 2013). These difficulties can hinder the production of diaspores, which forces the researchers to employ different sample sizes in germination studies. Furthermore, there has been no standard procedure for germination testing for these species (Santana et al. 2012; 
Ribeiro-Oliveira and Ranal 2014), which can also have motivated this wide range of sample sizes observed in the literature.

A classic example of the wide range of sample sizes in germination studies can be observed in Sautu et al. (2006), where the authors used samples from 100 to 400 seeds to make inferences about the physiological quality of seeds of 100 native species in a seasonal moist tropical forest in Panama. This sample size fluctuation can be detrimental to inferences about physiological quality of diaspores. Thus, could the sample size change the physiological inferences made from the germination measurements? Which measurement(s) would be the most robust against sample size fluctuation? The present study offers answers to these questions and still exposes peculiarities about measurements of the germination process regarding differences in sample size and physiological quality of diaspores.

\section{Materials and Methods}

Species studied, origin of the diaspores and classification of the samples

The tests were conducted with diaspores of six native tree species from the Brazilian Cerrado (Table 1). They are widely used as wood sources and in popular phytotherapy. They are also used in conservation and restoration projects (Carvalho 2003; 2006), mainly in areas of the Cerrado biome. This is one of the most threatened regions on Earth as a consequence of habitat fragmentation and degradation (CEPF 2015), and it is also an important hotspot due to its high biodiversity and high endemism among tropical savannas.

The diaspores were collected around Uberlândia, Minas Gerais, Brazil, or acquired as commercial lots from Fepagro, Bioflora and Instituto Florestal (Table 1). The choice of the genitor plant was dependent on the number of fertile individuals and on the quantity and quality of diaspores produced. The criteria to group diaspores in samples with different physiological qualities were defined by means of pre-testing conducted with different 
methods of segregation (seedcoat color, genitor plant and apparent physical integrity). Methods that led to apparent extremes in physiological quality were used to test our hypotheses (see 'Sample characterization' in Table 1). The grouping criteria of diaspores and the pre-germination treatment, if needed, varied according to the species studied (Table 1).

Enterolobium contortisiliquum (Vell.) Morong and Guazuma ulmifolia Lam. seeds were stored for five years in a cold chamber at $16.3 \pm 2.6^{\circ} \mathrm{C}$ and $22 \pm 1.8 \%$ relative moisture.

\section{Germination tests}

The tests were conducted in a germination chamber (Seedburo Equipment Company, model MPG - 2000), under continuous white fluorescent lamps at $26.2 \pm 2.5 \mathrm{C}$. This temperature is in the optimum range $\left(20-30^{\circ} \mathrm{C}\right)$ required for maximum diaspore germination of Cerrado tree species (Brancalion et al. 2010). The diaspores were sown in germination boxes (plastic boxes), over expansive vermiculite of superfine texture, with an expansion volume of $0.1 \mathrm{~m}^{3}$. The substrate was moistened to $70 \%$ of field capacity $(70 \mathrm{~mL}$ of distilled water for each $100 \mathrm{~mL}$ of vermiculite). During the experiments, supplementary irrigation was supplied when needed. For the Cecropia pachystachya Trécul germination test, we used Emanueli humidity chambers (Araújo and Ranal 2005). The germination assessments were performed daily at the same time. The germination criterion was embryo protrusion. At the end of the experiments, the remaining diaspores were dead with decomposing tissues.

\section{Experimental design}

The tests were performed using a completely randomized design in factorial structure (factorial ANOVA) with three fixed levels (three physiological qualities $\times$ three sample sizes). When factorial ANOVA is used, there are two possible statistical hypotheses (1) The factors analysed possess combined effects (interaction effect); thus, it is not necessary to 
analyse them separately (2) The factors do not possess combined effects, consequently they need to be analysed separately (main effects). This theory (see more in Neter et al. 1985; Steel et al. 1997; Quinn and Keough 2002) was considered when formulating the statistical null hypothesis. Thus, for the factorial interaction, the null hypothesis was that the effect of the sample size is independent of the physiological quality of the sample. When there was no factorial interaction, the main effects (factors without interaction) were studied.

We recognize a replicate as the set of diaspores that were maintained together in the randomization required by the experimental design, independently of the number of germination boxes. The number of replicates was fixed and equal to four. Due to the sample size factor, the experimental unit (replicate) consisted of one, two or four germination boxes, with 25 diaspores each. Thus, there were 25, 50 and 100 diaspores per experimental unit, totaling 100, 200 and 400 diaspores per sample. This was possible because the sample can be defined as a representative part of one population (Cochran 1977; Neter et al. 1985; Steel et al. 1997), from which it is possible to estimate population parameters (Kutner et al. 2004; Lorentz et al. 2010; Storck et al. 2010). Applying these concepts, it is possible to say that a sample is the set of diaspores with the same history, from their formation until their experimental condition, and this sample may be repeated $r$ times, in $r$ replicates (Santana and Ranal 2004). This means that the diaspores of the same treatment, within experimental designs, constitute one sample, because their history is common. Consequently, each replicate of the sample constitutes a sub-sample. This sub-sample is commonly called replicate/replication, plot or experimental unit (Neter et al. 1985; Kutner et al. 2004), the source of the data collected, a reflection of the treatment tested (Steel et al. 1997).

The reduced number of available diaspores of Ceiba speciosa and Guazuma ulmifolia made it very difficult to assemble three samples with different physiological quality. Thus, for these species, replicates were made using only one germination box. Independently of this 
particularity, we reiterate that the experimental design in studies for these species was the same as for the other species. The experimental unit of G. ulmifolia was composed of one germination box, with each unit containing 25,50 or 100 seeds, depending on the size of the sample studied. For C. speciosa, we used 400 seeds of each sample distributed into 16 replicates (each in one germination box) of 25 seeds each. Therefore, for this species, the different sample sizes were obtained by means of random mathematical combinations, i.e., results from each germination box were grouped randomly by procedures for data simulation in order to compose 25, 50 and 100 diaspores per experimental unit, totaling 100, 200 and 400 diaspores per sample.

\section{Characteristics evaluated}

The characteristics evaluated were calculated according to Ranal and Santana (2006), some of them discussed by McNair et al. (2012), including germinability $(G)$, time to first germination $\left(t_{f}\right)$, mean germination time $(\bar{t})$, time to last germination $\left(t_{l}\right)$, coefficient of variation of the germination time $\left(C V_{\mathrm{t}}\right)$, mean germination rate $(\bar{v})$, Maguire's rate $($ Rate $)$, and the synchronization index $(Z)$ of the germination process.

According to Labouriau (1983), germinability of one seed sample is the percentage of seeds (or diaspores as is the case in this paper) in which the germination process reaches the end, in experimental conditions, by means of the intraseminal growth that results in the protrusion (or emergence) of one live embryo. It means that germinability is the capacity or ability of diaspores to germinate. Mean germination time is the weighted mean of the germination time, where the number of seeds (or diaspores) germinated in the intervals of time established for data collection is used as weight (Ranal and Santana 2006). The first and last germinations are extremes in time (minimum and maximum, respectively) required for the germination process to be initiated and finalized. Coefficient of variation of the 
germination time is the dispersion of the germination process over time, which enables us to infer germination uniformity. Mean germination rate is a pure velocity measurement, with a concept similar to that used to measure velocity of chemical reactions (molecules per time unit). In the physical sense, this measurement is a frequency, since it is the reciprocal of the mean germination time (Ranal and Santana 2006). According to Brown and Mayer (1988), Maguire's rate is a time-weighted cumulative germination measurement that evaluates the velocity of germination and quantifies the seedling vigour. Synchronization index can evaluate the degree of overlapping of diaspore germination. More details about these characteristics can be obtained in Ranal and Santana (2006), and greater explanations about expressions and intermediated calculus can be observed in Ranal et al. (2009), which provides spreadsheets in supplementary materials to calculate these germination measurements.

We used the arithmetic mean of the ratio between number of sensitivity cases in the germination measurement by the total number of times this measurement was used in the study to summarize the frequency of sensitivity of the germination measurements to detect differences in sample size and physiological quality. The frequency of sensitivity was calculated to the factorial effect (i.e., interaction between sample size and physiological quality), and main effects (i.e., effect of sample size or physiological quality separately).

Furthermore, moisture content also was evaluated by drying, with eight replicates of 50 diaspores each. The drying temperature was $70{ }^{\circ} \mathrm{C}$ and the assessments were performed until constant mass was reached.

\section{Statistical analyses}

For the statistical analyses, we used Shapiro-Wilk to test normality of residuals of the ANOVA, and Levene to test the homogeneity among the variances, both at 0.01 significance. Once these assumptions were accepted, ANOVA was applied to the data and the Tukey's test 
was used for pairwise comparisons, both at 0.05 significance. Otherwise, we applied the Kruskal-Wallis test followed by the Dunn test to the binary combinations at a 0.05 significance. For some characteristics, in view of the $F$ test's robustness to minor violations of residual normality (Scheffé 1959) and limited availability of nonparametric tests designed for factorial experiments, we chose to perform parametric analyses of data that, when transformed, did not satisfy the ANOVA assumptions, but reduced the $F$ value of the Levene's test and/or increased the $W$ value of the Shapiro-Wilk test.

\section{Results}

The moisture content of diaspores in the different samples was low, independent of the species $(2.63 \% \leq$ moisture content $\leq 10.59 \%$; Supplementary Table S1). Three out of the six studied species exhibited diaspore moisture content that was dependent on the sample analysed (Cecropia pachystachya, Enterolobium contortisiliquum and Lafoensia pacari A. St.-Hil.; Supplementary Table S1).

Germinability, final time, mean time, and synchronization index had no sensitivity cases to sample size or to sample size and physiological quality; while, Maguire's rate, initial time, coefficient of variation of the germination time, and mean germination rate had at least one sensitivity case (Fig. 1). Germinability and mean germination time are highly sensitive measurements to detect differences in physiological quality, and final germination time is a poor measurement for this (Fig. 1). Maguire's rate is a very sensitive measurement to detect differences in sample size and physiological quality (Fig. 1).

These observations were statistically confirmed by the robustness of the analyses of the germination measurements. We observed that germinability, final time, mean germination time, and synchronization index were robust to increases in the number of diaspores in the sample (Tables 2-7). However, germinability proved to be more robust, since its results did 
not show variation even when the sample quality was extreme (Tables 2-7). On the other hand, the results for Maguire's rate, initial time, coefficient of variation of the germination time, and mean germination rate were influenced, at least for one of the species tested, by the number of diaspores in the sample. Among these measurements, the most susceptible (least robust) to an increase in diaspore number was Maguire's rate. The values of this measurement, independent of the species under consideration, always increased with an increase in sample size (Tables 2-7).

Results for Maguire's rate were also influenced by mean germination rate and germinability, since these characteristics are part of its composition. Thus, samples that showed diaspores with higher germinability and lower mean germination rate were considered, by this measurement, faster or equivalent to those that showed lower germinability and higher mean germination rate. An example of this association can be observed in Lafoensia pacari, where sample 1, with smaller mean germination rate and greater germinability values, was considered the fastest by Maguire's rate (Table 6). Another example of this interaction between germinability and mean germination rate can be observed in the seed test of Ceiba speciosa. Sample 3 of this species, with smaller germinability and greater mean germination rate, was considered the fastest by Maguire's rate (Table 3).

Details about values of statistics and probabilities used to analyse robustness of germination measurements regarding to differences in sample size, physiological quality and its interactions can be observed in supplementary material (Tables S2-S7).

\section{Discussion}

This is the first paper that quantifies the robustness of the measurements used to infer the physiological quality of diaspores in the germination process. Here, we demonstrate that sample size can affect some inferences about this process. This fact is critical for studies on 
native species that do not produce diaspores regularly, such as Copaifera langsdorffii Desf. (Pereira et al. 2009), and species with low production or with a high number of seeds without embryos (Mendes-Rodrigues et al. 2010; Ranal et al. 2010). These studies are frequently conducted with a wide range of sample sizes. This could incur in wrong inferences about seed germination and could compromise conservation efforts aimed at maintaining genetic variability.

The robustness of germinability, mean and final germination times, and synchronization index with respect to increases in sample size demonstrates that they are stable qualitative attributes that reliably measure the physiological quality of diaspores, independent of species and sample size. Among these measurements, germinability and mean germination time also possess high sensitivity to detect differences in physiological quality, but final germination time has low sensitivity. This indicates that germinability and mean germination time must be used for any germination study, but final germination time must be avoided in studies on physiological quality. The high robustness of germinability, even when the samples possessed distinct qualities, ratifies the importance given to this measurement by the international and national organizations that oversee and regulate seed commercialization.

Time (initial, mean, and final germination time) and synchronization measurements can express the species pattern as was observed by Rezende et al. (2015). This can explain the robustness of the synchronization index, and the initial and final germination time regarding differences in sample size. They also explain medium to low sensitivity to detect differences in physiological quality. Mean germination time is an exception to these time measurements, demonstrating its capacity to detect differences in physiological quality. This sensitivity to detect differences probably is associated to a greater capacity for the mean germination time to infer seed vigour, contrary to the other time measurements. 
The robustness of the time measurements and the synchronization index also demonstrates that once the diaspores are able to germinate (either from a natural absence of dormancy or as a result of pre-germination treatment), the germination process has a cadenced rhythm, much like a biological clock with a beginning, middle, and end, peculiar to each species. This can explain why the time measurements are associated to the pattern of a species, and it certainly contributes to the low sensitivity of the initial and final germination time to detect differences related to sample size and physiological quality. Thus, extremes in time seem to be an important botany tool for studies about characterization of the germination process in species.

The mean germination rate was not robust to variation in sample size in tests with Guazuma ulmifolia seeds. However, for this species the number of seeds inside each germination box was different $(25,50$ and 100 seeds). Thus, the increase in number of seeds per germination box was accompanied by an increase in mean germination rate. This can be related to the mutual stimulation phenomenon described by Brewbarker and Majumber (1961) and Ranal (1983), who studied pollen grain germination in phanerogams and spore germination in pteridophytes, respectively. The authors reported that studies carried out with a greater sample density showed higher germination percentages, probably as a result of volatile compounds produced by the dispersal units that served to signal and maximize germination. Studies on the role of volatile compounds in diaspore germination mainly discuss ethylene effects (Matilla 2000; Matilla and Matilla-Vásquez 2008), but additional volatile compounds, as yet unidentified, have recently been discovered (Molfetta et al. 2013), and some of them may be associated with the maximization of diaspore germination. In addition, mean germination rate possesses high sensitivity to differences in physiological quality, and low sensitivity to differences in sample size. This is a non-linear and pure velocity measurement (without interference of germinability) able to infer velocity of 
chemical reactions (Ranal and Santana 2006). Thus, mean germination rate must be considered in studies focusing on chemical alterations that occur in the germination process.

It appears that the coefficient of variation of germination time $\left(C V_{t}\right)$ is sensitive to changes in the physiological quality of the dispersal units, including changes in the uniformity of the germination process due to maternal effects, environmental conditions after dispersal, and the type of treatment to overcome dormancy. In this study, $C V_{t}$ was affected by sample size in Cecropia pachystachya and Guazuma ulmifolia when the diaspores were separated into samples by genitor plant. It is known that dispersal units are subject to strong maternal effects with consequences for physiological qualities associated with vigour (Roach and Wulff 1987; Wulff 1995) and dormancy (Roach and Wulff 1987; Wulff 1995; Weiner et al. 1997; Valencia-Díaz and Montaña 2005; Luzuriaga et al. 2006). As $C V_{t}$ reflects the temporal homogeneity of diaspore germination (Ranal and Santana 2006) and detects nuances in relative dormancy among diaspores belonging to the same sample, perhaps this measurement can be used to detect maternal effects in diaspores. It will be interesting to test other species to confirm this hypothesis, but it is important to take into consideration that the C. pachystachya achenes were freshly collected, whereas the G. ulmifolia seeds were stored during one year.

The efficacy of the thermal-shock pre-germination treatment, specifically for Guazuma ulmifolia, explains the $C V_{t}$ results obtained for that species. Some authors contest the efficacy of such treatment in uniformly overcoming dormancy (Zaidan and Carreira 2008). This can reduce the uniformity of diaspores in the germination process, mainly when the sample size is smaller, since the representativeness of a seed is greater in a universe of 100 seeds than in a universe of 200 or 400 seeds. This hypothesis is based on $C V_{t}$ results of Enterolobium contortisiliquum, whose samples were also formed from a genitor plant. For this species, $C V_{t}$ was not affected by sample size. Dormancy was overcome in $E$. contortisiliquum seeds by mechanical scarification, a very efficient pre-germination treatment 
(Zaidan and Carreira 2008). With this treatment, any pre-existing maternal effect that influenced seed coat hardness and, therefore, germination homogeneity, was no longer valid. This makes the samples lose the individual seed weight in relation to the set, and the germination process becomes more uniform. Thus, it is not only the sample size that affects the robustness of $C V_{t}$, but also the efficacy of the pre-germination treatment. As a consequence, $C V_{t}$ is a great measurement for studies focusing on dormancy and general aspects about germination physiology.

Similar to $C V_{t}$, time to first germination was affected by an increase in sample size for tests with diaspores of just two species, Lafoensia pacari and Schefflera morototoni (Aubl.) Maguire, Steyerm \& Frodin. In both cases, the first diaspore to germinate belonged to a larger sample. For L. pacari seeds, this can be explained by morphological discrepancies within and among the samples studied (samples determined by differences in seed coat colour and physical integrity of the seed). As seeds with a better visual aspect (in this case, the seed coat was light brown to dark brown or light brown and no apparent physical problem in the tegument) exhibit a greater likelihood of germination than those with a worse aspect (in this case, dark brown and brittle seed coat), there was an overvaluation of individual seeds in relation to the set. This overvaluation of one seed in relation to the sample is proved by the lower germinability, $C V_{t}$, and synchronization index in opposition to a high mean germination rate and mean germination time. The overvaluation explains the high initial time values for samples with low physiological quality as well as for small samples. This, together with the lack of efficacy of the thermal treatment to overcome dormancy (Zaidan and Carreira 2008), explains the influence of sample size on the results for time to first germination of pyrenes of S. morototoni. After all, even though several characteristics were considered to group the diaspores into samples, there are still individual diaspore-by-diaspore peculiarities with 
respect to dormancy (Ranal et al. 2010), and these can cause some of the diaspores (outliers) to germinate before the rest.

The inefficacy of thermal treatment can be explained by the degree of dormancy. Since there is variability in the degree of dormancy, high water temperature can reach the embryos of some diaspores faster, damaging them. This can retard or deter the germination process, depending on the temperature and duration of the treatment. In the case of pyrenes of Schefflera morototoni that exhibit multiple types and degrees of dormancy (Anastácio et al. 2010), the thermal shock was enough to damage the embryo, but not to kill it, retarding the germination process for diaspores with a low degree of dormancy. This inflates the number of outliers, resulting in measurements of initial time that exhibit greater sensitivity to sample size variation.

The germination measurement that demonstrated the least robustness with respect to increases in sample size was Maguire's rate. It is important to note that this measurement is extensively used by agronomists, foresters, and some ecologists to characterize the velocity of diaspore germination. Practicality led Maguire (1962) to present it as a tool to identify better samples, that is, samples with more seeds germinating in less time. However, the present paper demonstrates that Maguire's rate is sensitive to increases in sample size. Moreover, this measurement is strongly influenced by the relationship between germinability and mean germination rate. This relationship was observed by other authors (Brown and Mayer 1988; Ranal and Santana 2006). Thus, we can say that Maguire's rate is not a robust measurement of the germination velocity of diaspores with discrepant qualities, especially when sample sizes are different. However, Maguire's rate possesses a high sensitivity to differentiate samples with quality extremes, and can have a different interpretation for studies of the germination process, mainly for technical science, which needs to be found. 


\section{Conclusions}

Our results demonstrate that sample size can affect inferences about the germination process and so undermine restoration and/or conservation projects. The germinability of diaspores is the most stable measurement for the evaluation of the germination process. It is not influenced by sample size or sample quality. By contrast, Maguire's rate is an unstable measurement, since it is sensitive to variation in sample size and is balanced by germinability and mean germination rate. Thus, it is better to avoid Maguire's rate when inferring germination velocity.

\section{Acknowledgements}

We are grateful to the Coordenação de Aperfeiçoamento de Pessoal de Nível Superior (CAPES) for a scholarship provided to the first author; to the Fundação de Amparo à Pesquisa do Estado de Minas Gerais (FAPEMIG) for financial support; to Mr. Roger Hutchings and the team of the Editage for the English review of the manuscript.

Conflicts of interest: We have no conflicts of interest.

\section{References}

Anastácio, M.R., Santana, D.G., Oliveira, R.C., Batata, M.M., Oliveira, C.A.A. 2010. Maturação e qualidade física de frutos na germinação dos pirênios de Schefflera morototoni (Araliaceae). Cienc Florest 20: 429-437.

Araújo, E.A.P., Ranal, M.A. 2005. Câmara úmida para germinação de sementes e desenvolvimento inicial de plântulas (Câmara de Emanueli). Instituto Nacional Da Propriedade Industrial Intelectual, Brasil. PI0520543-3 A2.

Baskin, J.M., Baskin, C.C. 2004. A classification system for seed dormancy. Seed Sci Res 14(01): 1-16.

Brancalion, P.H.S., Novembre, A.D.L.C., Rodrigues, R.R. 2010. Temperatura ótima de germinação de sementes de espécies arbóreas brasileiras. Rev Bras Sementes 32(4): 15-21. 
Brewbarker, J.L., Majumber, S.K. 1961. Cultural studies of the pollen population effect and self-incompatibility inhibition. Am J Bot 48: 457-464.

Brown, R.F., Mayer, D.G. 1988. Representing cumulative germination: a critical analysis of single-value germination indices. Ann Bot 61: 117-125.

Carvalho, P.E.R. 2003. Espécies arbóreas brasileiras. Embrapa Informação Tecnológica, Brasília. v. 1.

Carvalho, P.E.R. 2006. Espécies arbóreas brasileiras. Embrapa Informação Tecnológica, Brasília. v. 2.

CEPF - Critical Ecosystem Partnership Fund. 2015. Cerrado. Available at http://www.cepf.net/resources/hotspots/South-America/Pages/Cerrado.aspx [accessed 2 May 2015].

Cochran, W.G.1977. Sampling techniques (3rd edition). John Wiley \& Sons, New York.

D'hondt, B., Hoffmann, M. 2011. A reassessment of the role of simple seed traits in mortality following herbivore ingestion. Plant Biol 13: 118-124.

Ferreira, W.R., Ranal, M.A., Santana, D.G., Nogueira, A.P.O. 2015. Germination and emergence measurements could group individuals and species? Braz J Bot DOI $10.1007 / \mathrm{s} 40415-015-0153-\mathrm{y}$

Ferreras, A.E., Galetto, L. 2010. From seed production to seedling establishment: important steps in an invasive process. Acta Oecol 36: 211-218.

Freitas, J.V., Pinard, M.A. 2008. Applying ecological knowledge to decisions about seed tree retention in selective logging in tropical forests. Forest Ecol and Manag 256: 1434-1442.

Guariguata, M.R. 2000. Seed and seedling ecology of tree species in neotropical secondary forests: management implications. Ecol Appl 10: 145-154.

Guariguata, M.R., Pinard, M.A. 1998. Ecological knowledge of regeneration from seed in neotropical forest trees: implications for natural forest management. Forest Ecol and Manag 112: 87-99.

Kutner, M.H., Neter, J., Nachtsheim, C.J., Li, W. 2004. Applied linear statistical models (5th edition). McGraw-Hill, New York.

Labouriau, L.G. 1983. A germinação das sementes. Organização dos Estados Americanos. Programa Regional de Desenvolvimento Científico e Tecnológico. Série de Biologia. Monografia 24.

Lorentz, L.H., Boligon, A.A., Storck, L., Lúcio, A.D. 2010. Plot size and precision in sunflower experiments. Sci Agric 67: 408-413.

Lorentz, L.H., Boligon, A.A., Storck, L., Lúcio, A.D. 2010. Plot size and precision in sunflower experiments. Sci Agric 67: 408-413.

Luzuriaga, A.L., Escudero, A., Pérez-García, F. 2006. Environmental maternal effects on seed morphology and germination in Sinapis arvensis (Cruciferae). Weed Res 46: 163-174. 
Maguire, J.D. 1962. Speed germination - aid in selection and evaluation for seedling emergence and vigor. Crop Sci 2: 176-177.

Matilla, A.J. 2000. Ethylene in seed formation and germination. Seed Sci Res 10: 111-126.

Matilla, A.J., Matilla-Vázquez, M.A. 2008. Involvement of ethylene in seed physiology. Plant Sci 175: 87-97.

McNair, J.N., Sunkara, A., Frobish, D. 2012. How to analyse seed germination data using statistical time-to-event analysis parametric and semi-parametric methods. Seed Sci Res 22: 77-95.

Mendes-Rodrigues, C., Araújo, F.P., Barbosa-Souza, C., Barbosa-Souza, V., Ranal, M.A., Santana, D.G., Oliveira, P.E. 2010. Multiple dormancy and maternal effect on Miconia ferruginata (Melastomataceae) seed germination, Serra de Caldas Novas, Goiás, Brazil. Braz J Bot 33: 93-105.

Molfetta, I., Ceccarini, L., Macchia, M., Flamin, G., Cioni, P.L. 2013. Abelmoschus esculentus (L.) Moench. and Abelmoschus moschatus Medik: seeds production and analysis of the volatile compounds. Food Chem DOI: http://dx.doi.org/10.1016/j.foodchem.2013.02.030

Neter, J., Wasserman, W., Kutner, M. 1985. Applied linear statistical models. IL: Richard D. Irwin, Homewood.

Pereira, R.S., Ranal, M.A., Santana, D.G. 2009. Emergência de plântulas oriundas de sementes recém-colhidas e armazenadas de Copaifera langsdorffii Desf. (Caesalpinoideae), Triângulo Mineiro, Brasil. Rev Árvore 33: 643-652.

Quinn, G.P., Keough, M.J. 2002. Experimental design and data analysis for biologists. Cambridge University Press, Cambridge.

Ranal, M.A. 1983. Efeito da temperatura e da intensidade luminosa no desenvolvimento de gametófitos de pteridófitas. Ph.D. Thesis, Universidade Estadual Paulista "Júlio de Mesquita Filho" (UNESP), Brazil.

Ranal, M.A., Santana, D.G. 2006. How and why to measure the germination process? Rev Bras Bot 29: 1-11.

Ranal, M.A., Santana, D.G.D., Ferreira, W.R., Mendes-Rodrigues, C. 2009. Calculating germination measurements and organizing spreadsheets. Braz J Bot 32(4): 849-855.

Ranal, M.A., Santana, D.G., Schiavini, I. 2010. Are there germination patterns for cerrado species? In: Del-Claro, K., Oliveira, P.S., Rico-Gray, V., Barbosa, A.A.A., Bonet, A., Scarano, F.R., Morales-Garzon, F.J., Villarnovo, G.C., Coelho, L., Sampaio, M.V., Quesada, M., Morris, M.R., Ramirez, N., Marçal Jr, O., Macedo, H.F., Marquis, R.J., Martins, R.P., Rodrigues, S.C., Luttge, U. (eds.), Encyclopedia of Life Support Systems (EOLSS), Tropical Biology and Conservation Management, vol. 10, Savannah Ecosystems. EOLSS Publishers [online encyclopedia] http://www.eolss.net, Oxford, UK, pp. 106-159.

Ribeiro-Oliveira, J.P., Ranal, M.A. 2014. Sementes florestais brasileiras: início precário, presente inebriante e o futuro, promissor? Cienc Florest 24: 771-784. 
Roach, D.A., Wulff, R.D. 1987. Maternal effects in plants. Annu Rev Ecol Syst 18: 209-235.

Santana, D.G., Ranal, M.A. 2004. Análise da germinação: um enfoque estatístico. Editora da UnB, Brasília.

Santana, D.G., Wielewicki, A.P., Salomão, A.N. 2012. Validation of quality tests for forest seed species. Seed Sci Res 22: 74-79.

Sautu, A., Baskin, J.M., Baskin, C.C., Condit, R. 2006. Studies on the biology of 100 native species of trees in a seasonal moist tropical forest, Panama, Central America. Forest Ecol Manag 234: 245-263.

Scheffé, H. 1959. The analysis of variance. Willey, New York. 477p.

Sobral, M., Guitián, J., Guitián, P., Larrinaga, R. 2013. Seed predators exert selection on the subindividual variation of seed size. Plant Biol, online. DOI: 10.1111/plb.12118

Steel, R.G.D., Torrie, J.H., Dickey, D.A. 1997. Principles and Procedures of Statistics: A Biometrical Approach (3rd edition). McGraw Hill Book, New York.

Storck, L., Cargnelutti Filho, A., Lopes, S.J., Toebe, M., Silveira, T.R. 2010. Experimental plan for single, double and triple hybrid corn. Maydica 55: 27-32.

Valencia-Díaz, S., Montaña, C. 2005. Temporal variability in the maternal environment and its effect on seed size and seed quality in Flourensia cernua DC. (Asteraceae). J Arid Environ 63: 686-695.

Weiner, J., Martinez, S., Muller-Scharer, H., Stoll, P., Schmid, B. 1997. How important are environmental maternal effects in plants? A study with Centaurea maculosa. J Ecol 85: 133142.

Wulff, R.D. 1995. Environmental maternal effects on seed quality and germination. In: Kigel, J., Galilei, G., Seed development and germination. New York, Marcel Dekker, pp. 491-505.

Zaidan, L.B.P., Carreira, R.C. 2008. Seed germination in Cerrado species. Braz J Plant Physiol 20: 167-181. 
Table 1. Geographical coordinates of the matrices, origin of the commercial lots, characterization of each sample studied, types of dormancy (sensu Baskin and Baskin 2004) and, when needed, pre-germination treatment to overcome diaspore dormancy. UTM: Universal Transverse Mercator. IF: Instituto Florestal de São Paulo. 1: Sample with low physiological quality; 2: Sample with medium physiological quality; 3: Sample with high physiological quality. Aquenes and pyrenes have one seed per dispersion unit.

\begin{tabular}{|c|c|c|c|c|c|c|c|c|c|}
\hline \multirow{2}{*}{ Species } & \multirow{2}{*}{$\begin{array}{l}\text { Sample/ } \\
\text { matrice }\end{array}$} & \multirow{2}{*}{$\begin{array}{c}\text { Geographical } \\
\text { coordinates (UTM) }\end{array}$} & \multirow{2}{*}{$\begin{array}{c}\text { Commercial } \\
\text { lots }\end{array}$} & \multirow{2}{*}{$\begin{array}{l}\text { Criteria of sample } \\
\text { formation }\end{array}$} & \multicolumn{3}{|c|}{ Sample characterization } & \multirow{2}{*}{$\begin{array}{l}\text { Types of } \\
\text { dormancy }\end{array}$} & \multirow{2}{*}{$\begin{array}{l}\text { Pre-germination } \\
\text { treatments }\end{array}$} \\
\hline & & & & & 1 & 2 & 3 & & \\
\hline $\begin{array}{l}\text { Cecropia pachystachya } \\
\text { Trécul (tree) }\end{array}$ & $\begin{array}{l}1 \\
2 \\
3 \\
\end{array}$ & $\begin{array}{l}789715-7906353 \\
779116-7909500 \\
779134-7906406 \\
\end{array}$ & & Genitor plant & $\begin{array}{c}\text { Achenes from matrix } \\
1\end{array}$ & $\begin{array}{l}\text { Achenes from } \\
\text { matrix } 2\end{array}$ & Achenes from matrix 3 & None & - \\
\hline $\begin{array}{l}\text { Ceiba speciosa (A. St.- } \\
\text { Hil.) Ravenna (tree) }\end{array}$ & $\begin{array}{c}1 \\
2 \\
3 \\
4 \\
5 \\
6 \\
7 \\
8 \\
9 \\
10 \\
11 \\
\end{array}$ & $\begin{array}{c}- \\
786014-7923376 \\
786051-7923299 \\
779110-7909324 \\
779116-7909324 \\
779050-7909577 \\
789200-7906117 \\
786118-7907362 \\
786430-7907680 \\
786277-7907778 \\
186607-7984169\end{array}$ & Bioflora & $\begin{array}{l}\text { Seed coat colour and } \\
\text { seed turgidity }\end{array}$ & $\begin{array}{l}\text { Seeds slightly turgid } \\
\text { with black seed coat } \\
\text { colour }\end{array}$ & $\begin{array}{l}\text { Seeds turgid } \\
\text { with black } \\
\text { seed coat } \\
\text { colour }\end{array}$ & $\begin{array}{l}\text { Seeds turgid with brown } \\
\text { seed coat colour }\end{array}$ & None & - \\
\hline $\begin{array}{l}\text { Enterolobium } \\
\text { contortisiliquum (Vell.) } \\
\text { Morong (tree) }\end{array}$ & $\begin{array}{l}1 \\
2 \\
3\end{array}$ & $\begin{array}{c}803144-917156 \\
803774-918069 \\
0792312-7919670\end{array}$ & & Genitor plant & Seeds from matrix 1 & $\begin{array}{l}\text { Seeds from } \\
\text { matrix } 2\end{array}$ & Seeds from matrix 3 & Physical & 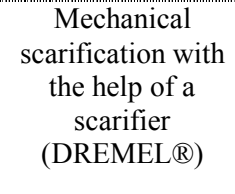 \\
\hline $\begin{array}{l}\text { Guazuma ulmifolia } \\
\text { Lam. (tree) }\end{array}$ & $\begin{array}{l}1 \\
2 \\
3\end{array}$ & $\begin{array}{c}0811991-7908104 \\
07993148-7927004 \\
0796600-7923331\end{array}$ & & Genitor plant & Seeds from matrix 1 & $\begin{array}{l}\text { Seeds from } \\
\text { matrix } 2\end{array}$ & Seeds from matrix 3 & Physical & $\begin{array}{l}\text { Thermal treatment } \\
\text { (soaking in water } \\
\text { at } 90^{\circ} \mathrm{C} \text { for } 24 \mathrm{~h} \text { ) }\end{array}$ \\
\hline $\begin{array}{l}\text { Lafoensia pacari A. St.- } \\
\text { Hil. (tree) }\end{array}$ & $\begin{array}{l}1 \\
2 \\
3\end{array}$ & $\begin{array}{l}- \\
- \\
-\end{array}$ & $\begin{array}{l}\text { Bioflora } \\
\text { Fepagro } \\
\text { IF }\end{array}$ & $\begin{array}{l}\text { Seed coat colour and } \\
\text { physical integrity of the } \\
\text { seed }\end{array}$ & $\begin{array}{l}\text { Seed coat light brown } \\
\text { and no apparent } \\
\text { physical problem }\end{array}$ & $\begin{array}{l}\text { Seed coat } \\
\text { dark brown } \\
\text { and brittle }\end{array}$ & $\begin{array}{l}\text { Seed coat light brown to } \\
\text { dark brown and no } \\
\text { apparent physical } \\
\text { problem }\end{array}$ & None & - \\
\hline $\begin{array}{l}\text { Schefflera morototoni } \\
\text { (Aubl.) Maguire, } \\
\text { Steyerm. \& Frodin } \\
\text { (tree) }\end{array}$ & $\begin{array}{l}1 \\
2 \\
3 \\
4\end{array}$ & $\begin{array}{l}783822-7915813 \\
776674-7924587 \\
781734-7923665 \\
788782-7923700 \\
\end{array}$ & & $\begin{array}{l}\text { Oxidation, contraction } \\
\text { and apparent absence of } \\
\text { embryo in freshly } \\
\text { processed pyrenes }\end{array}$ & $\begin{array}{l}\text { Pyrenes with apparent } \\
\text { absence of embryo }\end{array}$ & $\begin{array}{l}\text { Pyrenes } \\
\text { oxidized and } \\
\text { embryo } \\
\text { apparently } \\
\text { retracted }\end{array}$ & $\begin{array}{l}\text { Pyrenes intact, } \\
\text { apparently normal }\end{array}$ & $\begin{array}{l}\text { Morpho- } \\
\text { physiologi } \\
\text { cal and } \\
\text { Physical }\end{array}$ & $\begin{array}{l}\text { Thermal treatment } \\
\text { (soaking in water } \\
\text { at } 60^{\circ} \mathrm{C} \text { for } 12 \mathrm{~h} \text { ) }\end{array}$ \\
\hline
\end{tabular}


Table 2. Measurements of time, germinability, velocity, uniformity and synchrony of germination of achenes of Cecropia pachystachya Trécul belonging to different samples and measured from three sample sizes (S.S.) ${ }^{1}$. 1: Sample with low physiological quality; 2: Sample with medium physiological quality; 3: Sample with high physiological quality.

\begin{tabular}{|c|c|c|c|c|c|}
\hline \multirow{2}{*}{ Characteristic } & \multicolumn{5}{|c|}{ Sample } \\
\hline & S.S. & 1 & 2 & 3 & Mean \\
\hline \multirow{4}{*}{$t_{f}$ (day) } & 100 & 7.75 & 8.75 & 8.00 & $8.17 \mathrm{a}$ \\
\hline & 200 & 7.75 & 8.00 & 8.00 & $7.92 \mathrm{a}$ \\
\hline & 400 & 7.50 & 7.75 & 7.25 & $7.50 \mathrm{a}$ \\
\hline & Mean & 7.67A & $8.17 \mathrm{~A}$ & $7.75 \mathrm{~A}$ & \\
\hline \multirow{4}{*}{$t_{l}$ (day) } & 100 & 22.00 & 26.50 & 30.75 & $26.42 a$ \\
\hline & 200 & 22.50 & 32.00 & 32.25 & $28.92 \mathrm{a}$ \\
\hline & 400 & 25.75 & 36.75 & 37.00 & $33.17 \mathrm{a}$ \\
\hline & Mean & $23.42 \mathrm{~A}$ & $31.75 \mathrm{~A}$ & $33.33 \mathrm{~A}$ & \\
\hline \multirow{4}{*}{$\bar{t}$ (day) } & 100 & 11.44 & 12.72 & 13.50 & $12.53 \mathrm{a}$ \\
\hline & 200 & 12.11 & 12.95 & 13.90 & $12.99 a$ \\
\hline & 400 & 10.83 & 13.45 & 13.52 & $12.60 \mathrm{a}$ \\
\hline & Mean & $11.46 \mathrm{~A}$ & $13.04 \mathrm{AB}$ & 13.64B & \\
\hline \multirow{4}{*}{$G(\%)$} & 100 & 48.48 & 60.23 & 60.80 & $56.50 \mathrm{a}$ \\
\hline & 200 & 47.02 & 53.85 & 65.01 & $55.29 \mathrm{a}$ \\
\hline & 400 & 51.08 & 57.57 & 68.53 & $59.06 \mathrm{a}$ \\
\hline & Mean & $48.86 \mathrm{C}$ & $57.21 \mathrm{~B}$ & $64.78 \mathrm{~A}$ & \\
\hline \multirow{4}{*}{ Rate (achene day ${ }^{-1}$ ) } & 100 & 1.35 & 1.41 & 1.60 & $1.45 \mathrm{c}$ \\
\hline & 200 & 2.47 & 2.82 & 3.34 & $2.88 \mathrm{~b}$ \\
\hline & 400 & 5.97 & 5.90 & 7.18 & $6.35 \mathrm{a}$ \\
\hline & Mean & $3.26 \mathrm{~B}$ & $3.38 \mathrm{~B}$ & $4.04 \mathrm{~A}$ & \\
\hline \multirow{4}{*}{$\bar{v}\left(\right.$ day $\left.^{-1}\right)$} & 100 & 0.0875 & 0.0800 & 0.0750 & $0.0808 \mathrm{a}$ \\
\hline & 200 & 0.0825 & 0.0750 & 0.0725 & $0.0767 \mathrm{a}$ \\
\hline & 400 & 0.0900 & 0.0775 & 0.0750 & $0.0808 \mathrm{a}$ \\
\hline & Mean & $0.0867 \mathrm{~A}$ & $0.0775 \mathrm{AB}$ & $0.0742 \mathrm{~B}$ & \\
\hline \multirow[t]{4}{*}{$C V_{t}(\%)$} & 100 & 14.16 & 27.41 & 15.59 & $19.05^{\mathrm{a}}$ \\
\hline & 200 & 16.30 & 31.20 & 22.59 & $23.36 \mathrm{ab}$ \\
\hline & 400 & 20.03 & 29.81 & 33.41 & $27.75 b$ \\
\hline & Mean & $16.83 \mathrm{~A}$ & $29.47 \mathrm{~B}$ & $23.86 \mathrm{AB}$ & \\
\hline \multirow[t]{4}{*}{$Z$} & 100 & 0.1335 & 0.1428 & 0.0991 & $0.1251 \mathrm{a}$ \\
\hline & 200 & 0.1046 & 0.0926 & 0.0800 & $0.0924 \mathrm{a}$ \\
\hline & 400 & 0.1461 & 0.0864 & 0.0882 & $0.1069 \mathrm{a}$ \\
\hline & Mean & $0.1281 \mathrm{~A}$ & $0.1073 \mathrm{~A}$ & $0.0891 \mathrm{~A}$ & \\
\hline
\end{tabular}

${ }^{1}$ For each measurement, means followed by distinct letters (capital letters in rows and lowercase in columns) differ by the Tukey or Dunn test at 0.05 probability. $t_{f}$ : time to first germination; $t_{l}$ : time to last germination; $\bar{t}$ : mean germination time; $G$ : germinability; Rate: Maguire's rate; $\bar{v}$ : mean germination rate; $C V_{t}$ : coefficient of variation of the germination time; $Z$ : synchronization index. The statistical analyses for $G$ and $C V_{t}$ were based on transformed data $(\operatorname{arcsine} \sqrt{x / 100})$. 
Table 3. Measurements of time, germinability, velocity, uniformity and synchrony of germination of seeds of Ceiba speciosa (A. St.-Hil.) Ravenna belonging to different samples and measured from three sample sizes (S.S.) ${ }^{1}$. 1: Sample with low physiological quality; 2: Sample with medium physiological quality; 3: Sample with high physiological quality.

\begin{tabular}{|c|c|c|c|c|c|}
\hline \multirow[t]{2}{*}{ Characteristic } & \multicolumn{5}{|c|}{ Sample } \\
\hline & S.S. & 1 & 2 & 3 & Mean \\
\hline \multirow{4}{*}{$t_{f}$ (day) } & 100 & 3.75 & 2.25 & 2.75 & $2.92 \mathrm{a}$ \\
\hline & 200 & 3.25 & 2.25 & 3.00 & $2.83 \mathrm{a}$ \\
\hline & 400 & 2.75 & 2.00 & 2.50 & $2.42 \mathrm{a}$ \\
\hline & Mean & $3.25 \mathrm{~B}$ & $2.17 \mathrm{~A}$ & $2.75 \mathrm{AB}$ & \\
\hline \multirow{4}{*}{$t_{l}$ (day) } & 100 & 18.75 & 13.25 & 12.50 & $14.83 a$ \\
\hline & 200 & 25.50 & 17.75 & 12.50 & $18.58 \mathrm{a}$ \\
\hline & 400 & 36.00 & 17.50 & 16.75 & $23.42 \mathrm{a}$ \\
\hline & Mean & $26.75 \mathrm{~A}$ & $16.17 \mathrm{~A}$ & $13.92 \mathrm{~A}$ & \\
\hline \multirow{4}{*}{$\bar{t}$ (day) } & 100 & 2.81 & 2.30 & 2.31 & $2.47 \mathrm{a}$ \\
\hline & 200 & 2.78 & 2.29 & 2.32 & $2.46 \mathrm{a}$ \\
\hline & 400 & 2.76 & 2.34 & 2.29 & $2.46 \mathrm{a}$ \\
\hline & Mean & $2.78 \mathrm{~B}$ & $2.29 \mathrm{~A}$ & $2.32 \mathrm{~A}$ & \\
\hline \multirow{4}{*}{$G(\%)$} & 100 & 83.00 & 62.00 & 61.00 & $68.67 \mathrm{a}$ \\
\hline & 200 & 82.00 & 61.50 & 54.00 & $65.83 a$ \\
\hline & 400 & 82.25 & 61.50 & 59.25 & $67.67 \mathrm{a}$ \\
\hline & Mean & $82.42 \mathrm{~A}$ & $61.67 \mathrm{~B}$ & $58.08 \mathrm{~B}$ & \\
\hline \multirow{4}{*}{ Rate $\left(\right.$ seed day $\left.{ }^{-1}\right)$} & 100 & 1.35 & 1.41 & 1.60 & $1.45 \mathrm{c}$ \\
\hline & 200 & 2.47 & 2.82 & 3.34 & $2.88 \mathrm{~b}$ \\
\hline & 400 & 5.97 & 5.90 & 7.18 & $6.35 \mathrm{a}$ \\
\hline & Mean & $3.26 \mathrm{~B}$ & $3.38 \mathrm{~B}$ & $4.04 \mathrm{~A}$ & \\
\hline \multirow{4}{*}{$\bar{v}\left(\right.$ day $\left.^{-1}\right)$} & 100 & 0.1450 & 0.1975 & 0.1950 & $0.1792 \mathrm{a}$ \\
\hline & 200 & 0.1375 & 0.1975 & 0.1875 & $0.1742 \mathrm{a}$ \\
\hline & 400 & 0.1325 & 0.1950 & 0.1825 & $0.1700 \mathrm{a}$ \\
\hline & Mean & $0.1383 \mathrm{~B}$ & $0.1967 \mathrm{~A}$ & $0.1883 \mathrm{~A}$ & \\
\hline \multirow{4}{*}{$C V_{t}(\%)$} & 100 & 48.54 & 53.72 & 45.39 & $49.21 \mathrm{a}$ \\
\hline & 200 & 61.51 & 55.28 & 40.36 & $52.38 \mathrm{a}$ \\
\hline & 400 & 77.76 & 55.57 & 45.81 & $59.71 \mathrm{a}$ \\
\hline & Mean & $62.61 \mathrm{~B}$ & $54.85 \mathrm{AB}$ & $43.85 \mathrm{~A}$ & \\
\hline \multirow{4}{*}{$Z$} & 100 & 0.1538 & 0.2101 & 0.1944 & $0.1861 \mathrm{a}$ \\
\hline & 200 & 0.1140 & 0.1917 & 0.1904 & $0.1654 \mathrm{a}$ \\
\hline & 400 & 0.1199 & 0.1794 & 0.1880 & $0.1624 \mathrm{a}$ \\
\hline & Mean & $0.1292 \mathrm{~A}$ & $0.1937 \mathrm{~A}$ & $0.1909 \mathrm{~A}$ & \\
\hline
\end{tabular}

${ }^{1}$ For each measurement, means followed by distinct letters (capital letters in rows and lowercase in columns) differ by the Tukey or Dunn test at 0.05 probability. $t_{f}$ : time to first germination; $t_{l}$ : time to last germination; $\bar{t}$ : mean germination time; $G$ : germinability; Rate: Maguire's rate; $\bar{v}$ : mean germination rate; $C V_{t}$ : coefficient of variation of the germination time; $Z$ : synchronization index. The statistical analyses for $\bar{t}$ and $G$ were based on transformed data, with $\bar{t}$ transformed by $\sqrt{x}$ and $G$ by arcsine $\sqrt{x / 100}(\operatorname{arcsine} \sqrt{x / 100})$. 
Table 4. Measurements of time, germinability, velocity, uniformity and synchrony of germination of seeds of Enterolobium contortisiliquum (Vell.) Morong belonging to different samples and measured from three sample sizes (S.S.) ${ }^{1}$. 1 : Sample with low physiological quality; 2: Sample with medium physiological quality; 3: Sample with high physiological quality.

\begin{tabular}{|c|c|c|c|c|c|}
\hline \multirow[t]{2}{*}{ Characteristic } & \multicolumn{5}{|c|}{ Sample } \\
\hline & S.S. & 1 & 2 & 3 & Mean \\
\hline \multirow{4}{*}{$t_{f}$ (day) } & 100 & 3.50 & 3.00 & 3.00 & $3.17 \mathrm{a}$ \\
\hline & 200 & 3.00 & 2.50 & 3.00 & $2.83 \mathrm{a}$ \\
\hline & 400 & 3.00 & 2.50 & 2.75 & $2.75 \mathrm{a}$ \\
\hline & Mean & $3.17 \mathrm{~A}$ & $2.67 \mathrm{~A}$ & $2.92 \mathrm{~A}$ & \\
\hline \multirow{4}{*}{$t_{l}$ (day) } & 100 & 5.25 & 5.50 & 6.00 & $5.58 \mathrm{a}$ \\
\hline & 200 & 6.50 & 5.00 & 6.50 & $6.00 \mathrm{a}$ \\
\hline & 400 & 7.75 & 5.25 & 6.00 & $6.33 \mathrm{a}$ \\
\hline & Mean & $6.50 \mathrm{~A}$ & $5.25 \mathrm{~A}$ & $6.17 \mathrm{~A}$ & \\
\hline \multirow{4}{*}{$\bar{t}$ (day) } & 100 & 4.86 & 3.82 & 4.19 & $4.10 \mathrm{a}$ \\
\hline & 200 & 4.69 & 3.66 & 4.04 & $4.04 \mathrm{a}$ \\
\hline & 400 & 4.90 & 3.68 & 3.72 & $3.72 \mathrm{a}$ \\
\hline & Mean & $4.82 \mathrm{C}$ & $3.72 \mathrm{~A}$ & $3.98 \mathrm{~B}$ & \\
\hline \multirow{4}{*}{$G(\%)$} & 100 & 98.00 & 98.00 & 97.00 & $97.67 \mathrm{a}$ \\
\hline & 200 & 98.50 & 98.50 & 99.00 & $98.67 \mathrm{a}$ \\
\hline & 400 & 98.75 & 97.75 & 98.75 & $98.33 \mathrm{a}$ \\
\hline & Mean & $98.42 \mathrm{~A}$ & $97.75 \mathrm{~A}$ & $98.50 \mathrm{~A}$ & \\
\hline \multirow{4}{*}{ Rate (seed day ${ }^{-1}$ ) } & 100 & $5.24 \mathrm{Ac}$ & $6.54 \mathrm{Ac}$ & $6.08 \mathrm{Abc}$ & 5.95 \\
\hline & 200 & $10.84 \mathrm{Cb}$ & $13.84 \mathrm{Ab}$ & $12.73 \mathrm{Bb}$ & 12.47 \\
\hline & 400 & $20.80 \mathrm{Ba}$ & $27.56 \mathrm{Aa}$ & $27.31 \mathrm{Aa}$ & 25.22 \\
\hline & Mean & 12.29 & 15.98 & 15.37 & \\
\hline \multirow{4}{*}{$\bar{v}\left(\right.$ day $\left.^{-1}\right)$} & 100 & 0.2050 & 0.2600 & 0.2400 & $0.2350 \mathrm{a}$ \\
\hline & 200 & 0.2150 & 0.2750 & 0.2458 & $0.2458 \mathrm{a}$ \\
\hline & 400 & 0.2025 & 0.2700 & 0.2700 & $0.2475 \mathrm{a}$ \\
\hline & Mean & $0.2075 \mathrm{C}$ & $0.2683 \mathrm{~A}$ & $0.2525 \mathrm{~B}$ & \\
\hline \multirow{4}{*}{$C V_{t}(\%)$} & 100 & 17.71 & 17.22 & 18.86 & $17.93 a$ \\
\hline & 200 & 17.71 & 16.28 & 20.66 & $18.01 \mathrm{a}$ \\
\hline & 400 & 17.23 & 18.54 & 17.45 & $17.74 \mathrm{a}$ \\
\hline & Mean & $17.35 \mathrm{~A}$ & $17.35 \mathrm{~A}$ & $18.99 \mathrm{~A}$ & \\
\hline \multirow{4}{*}{$Z$} & 100 & 0.3450 & 0.4600 & 0.3700 & $0.3917 \mathrm{a}$ \\
\hline & 200 & 0.3500 & 0.4525 & 0.3917 & $0.4000 \mathrm{a}$ \\
\hline & 400 & 0.3700 & 0.4175 & 0.4450 & $0.4108 \mathrm{a}$ \\
\hline & Mean & $0.3550 \mathrm{~B}$ & $0.4433 \mathrm{~A}$ & $0.4042 \mathrm{AB}$ & \\
\hline
\end{tabular}

${ }^{1}$ For each measurement, means followed by distinct letters (capital letters in rows and lowercase in columns) differ by the Tukey or Dunn test at 0.05 probability. $t_{f}$ : time to first germination; $t_{l}$ : time to last germination; $\bar{t}$ : mean germination time; $G$ : germinability; Rate: Maguire's rate; $\bar{v}$ : mean germination rate; $C V_{t}$ : coefficient of variation of the germination time; $Z$ : synchronization index. The statistical analyses for $\bar{t}, G$, Rate, $\bar{v}, C V_{t}$ and $Z$ were based on transformed data, with $\bar{t}$ transformed by $\sqrt{x} ; G$ and $C V_{t}$ by arcsine $\sqrt{x / 100}$; and Rate, $\bar{v}$, and $Z$ by $\sqrt{x+1}$. 
Table 5. Measurements of time, germinability, velocity, uniformity and synchrony of germination of seeds of Guazuma ulmifolia Lam. belonging to different samples and measured from three sample sizes (S.S.) ${ }^{1}$. 1: Sample with low physiological quality; 2: Sample with medium physiological quality; 3: Sample with high physiological quality.

\begin{tabular}{|c|c|c|c|c|c|}
\hline \multirow[t]{2}{*}{ Characteristic } & \multicolumn{5}{|c|}{ Sample } \\
\hline & S.S. & 1 & 2 & 3 & Mean \\
\hline \multirow{4}{*}{$t_{f}$ (day) } & 100 & 1.00 & 1.25 & 1.00 & $1.08 \mathrm{a}$ \\
\hline & 200 & 1.25 & 1.75 & 1.00 & $1.33 \mathrm{a}$ \\
\hline & 400 & 1.25 & 1.00 & 1.00 & $1.08 \mathrm{a}$ \\
\hline & Mean & $1.17 \mathrm{~A}$ & $1.33 \mathrm{~A}$ & $1.00 \mathrm{~A}$ & \\
\hline \multirow{4}{*}{$t_{l}$ (day) } & 100 & 12.75 & 14.25 & 25.75 & $17.58 \mathrm{a}$ \\
\hline & 200 & 32.25 & 15.75 & 18.25 & $22.08 \mathrm{a}$ \\
\hline & 400 & 20.00 & 23.25 & 21.75 & $21.67 \mathrm{a}$ \\
\hline & Mean & $21.67 \mathrm{~A}$ & $17.75 \mathrm{~A}$ & $21.92 \mathrm{~A}$ & \\
\hline \multirow{4}{*}{$\bar{t}$ (day) } & 100 & 2.89 & 4.81 & 4.92 & $4.21 \mathrm{a}$ \\
\hline & 200 & 3.77 & 4.22 & 4.94 & $4.31 \mathrm{a}$ \\
\hline & 400 & 3.51 & 4.17 & 4.94 & $4.21 \mathrm{a}$ \\
\hline & Mean & $3.39 \mathrm{~A}$ & $4.40 \mathrm{~B}$ & 4.93B & \\
\hline \multirow{4}{*}{$G(\%)$} & 100 & 92.00 & 90.00 & 95.50 & $92.50 \mathrm{a}$ \\
\hline & 200 & 90.00 & 86.00 & 93.50 & $89.83 a$ \\
\hline & 400 & 93.00 & 86.25 & 92.25 & $90.50 \mathrm{a}$ \\
\hline & Mean & & $87.42 \mathrm{~B}$ & $93.75 \mathrm{~A}$ & \\
\hline \multirow{4}{*}{ Rate (seed day ${ }^{-1}$ ) } & 100 & 11.38 & 7.57 & 11.06 & $9.99 \mathrm{c}$ \\
\hline & 200 & 18.61 & 14.07 & 16.04 & $16.24 b$ \\
\hline & 400 & 34.71 & 29.33 & 30.72 & $31.58 \mathrm{a}$ \\
\hline & Mean & $21.54 \mathrm{~A}$ & $16.98 \mathrm{C}$ & $19.27 \mathrm{~B}$ & \\
\hline \multirow{4}{*}{$\bar{v}\left(\right.$ day $\left.^{-1}\right)$} & 100 & $0.3850 \mathrm{Aa}$ & $0.2250 \mathrm{Ba}$ & $0.2075 \mathrm{Ba}$ & 0.2725 \\
\hline & 200 & $0.2725 \mathrm{Ab}$ & $0.2375 \mathrm{Aa}$ & $0.2025 \mathrm{Ab}$ & 0.2375 \\
\hline & 400 & $0.2875 \mathrm{Ab}$ & $0.2425 \mathrm{ABa}$ & $0.2025 \mathrm{Bc}$ & 0.2442 \\
\hline & Mean & 0.3150 & 0.2350 & 0.2042 & \\
\hline \multirow[t]{4}{*}{$C V_{t}(\%)$} & 100 & $89.41 \mathrm{Aa}$ & 210.20Aab & $426.99 \mathrm{Ab}$ & 242.20 \\
\hline & 200 & $128.07 \mathrm{Aa}$ & $285.62 \mathrm{Aa}$ & $279.17 \mathrm{Aa}$ & 230.95 \\
\hline & 400 & $475.66 \mathrm{Ba}$ & $462.17 \mathrm{Aa}$ & $347.17 \mathrm{Aa}$ & 428.33 \\
\hline & Mean & 231.05 & 319.33 & 351.12 & \\
\hline \multirow[t]{4}{*}{$Z$} & 100 & 0.3075 & 0.1625 & 0.1550 & $0.2083 \mathrm{a}$ \\
\hline & 200 & 0.3250 & 0.1850 & 0.1250 & $0.2117 \mathrm{a}$ \\
\hline & 400 & 0.3400 & 0.1875 & 0.1275 & $0.2183 \mathrm{a}$ \\
\hline & Mean & $0.3242 \mathrm{~A}$ & $0.1783 \mathrm{~B}$ & $0.1358 \mathrm{C}$ & \\
\hline
\end{tabular}

${ }^{1}$ For each measurement, means followed by distinct letters (capital letters in rows and lowercase in columns) differ by the Tukey or Dunn test at 0.05 probability. $t_{f}$ : time to first germination; $t_{l}$ : time to last germination; $\bar{t}$ : mean germination time; G: germinability; Rate: Maguire's rate; $\bar{v}$ : mean germination rate; $C V_{t}$ : coefficient of variation of the germination time; $Z$ : synchronization index. The statistical analyses for $G$, Rate, $\bar{v}, C V_{t}$ and $Z$ were based on transformed data, with $G$ and $C V_{t}$ transformed by arcsine $\sqrt{x / 100}$; and Rate, $\bar{v}$, and $Z$ by $\sqrt{x+1}$. 
Table 6. Measurements of time, germinability, velocity, uniformity and synchrony of germination of seeds of Lafoensia pacari A. St.-Hil. belonging to different samples and measured from three sample sizes (S.S.) ${ }^{1}$. 1: Sample with low physiological quality; 2: Sample with medium physiological quality; 3: Sample with high physiological quality.

\begin{tabular}{|c|c|c|c|c|c|}
\hline \multirow[t]{2}{*}{ Characteristic } & \multicolumn{4}{|c|}{ Sample } & \multirow[b]{2}{*}{ Mean } \\
\hline & S.S. & 1 & 2 & 3 & \\
\hline \multirow{4}{*}{$t_{f}$ (day) } & 100 & 7.00 & 5.00 & 6.00 & $6.00 \mathrm{~b}$ \\
\hline & 200 & 6.50 & 4.25 & 6.00 & $5.58 \mathrm{ab}$ \\
\hline & 400 & 6.00 & 4.00 & 5.50 & $5.17 \mathrm{a}$ \\
\hline & Mean & $6.50 \mathrm{~B}$ & $4.42 \mathrm{~A}$ & $5.83 \mathrm{~B}$ & \\
\hline \multirow{4}{*}{$t_{l}$ (day) } & 100 & 15.75 & 13.50 & 18.00 & $15.75 a$ \\
\hline & 200 & 17.00 & 16.00 & 16.25 & $16.42 \mathrm{a}$ \\
\hline & 400 & 18.50 & 17.75 & 17.25 & $17.83 \mathrm{a}$ \\
\hline & Mean & $17.08 \mathrm{~A}$ & $15.75 \mathrm{~A}$ & $17.17 \mathrm{~A}$ & \\
\hline \multirow{4}{*}{$\bar{t}$ (day) } & 100 & 10.62 & 8.65 & 11.22 & $10.16 a$ \\
\hline & 200 & 10.48 & 8.36 & 10.40 & $9.74 a$ \\
\hline & 400 & 10.42 & 7.68 & 10.30 & $9.47 \mathrm{a}$ \\
\hline & Mean & $10.51 \mathrm{~B}$ & $8.23 \mathrm{~A}$ & 10.64B & \\
\hline \multirow{4}{*}{$G(\%)$} & 100 & 99.00 & 55.00 & 67.00 & $73.67 \mathrm{a}$ \\
\hline & 200 & 98.00 & 54.00 & 61.50 & $71.17 \mathrm{a}$ \\
\hline & 400 & 97.00 & 61.00 & 65.50 & $74.50 \mathrm{a}$ \\
\hline & Mean & $98.00 \mathrm{~A}$ & $56.67 \mathrm{C}$ & $64.67 \mathrm{~B}$ & \\
\hline \multirow{4}{*}{ Rate (seed day ${ }^{-1}$ ) } & 100 & 2.43 & 1.97 & 1.63 & $2.01 \mathrm{c}$ \\
\hline & 200 & 4.95 & 3.70 & 3.13 & $3.93 b$ \\
\hline & 400 & 9.66 & 8.84 & 6.92 & $8.47 \mathrm{a}$ \\
\hline & Mean & $5.68 \mathrm{~A}$ & $4.84 \mathrm{~B}$ & $3.89 \mathrm{C}$ & \\
\hline \multirow{4}{*}{$\bar{v}\left(\right.$ day $\left.^{-1}\right)$} & 100 & 0.0950 & 0.1200 & 0.0900 & $0.1017 \mathrm{a}$ \\
\hline & 200 & 0.0975 & 0.1225 & 0.0975 & $0.1058 \mathrm{a}$ \\
\hline & 400 & 0.0975 & 0.1300 & 0.0950 & $0.1075 a$ \\
\hline & Mean & $0.0967 \mathrm{~B}$ & $0.1242 \mathrm{~A}$ & $0.0942 \mathrm{~B}$ & \\
\hline \multirow[t]{4}{*}{$C V_{t}(\%)$} & 100 & 100.00 & 19.18 & 32.26 & $27.63 a$ \\
\hline & 200 & 22.98 & 35.20 & 22.98 & $27.33 \mathrm{a}$ \\
\hline & 400 & 18.82 & 36.24 & 27.11 & $27.39 \mathrm{a}$ \\
\hline & Mean & $20.33 \mathrm{~A}$ & $34.56 \mathrm{~B}$ & $26.19 \mathrm{~A}$ & \\
\hline \multirow{4}{*}{$Z$} & 100 & 0.1875 & 0.1525 & 0.1000 & $0.1467 a$ \\
\hline & 200 & 0.1825 & 0.1100 & 0.1250 & $0.1392 \mathrm{a}$ \\
\hline & 400 & 0.1875 & 0.1375 & 0.1125 & $0.1458 \mathrm{a}$ \\
\hline & Mean & $0.1858 \mathrm{~A}$ & $0.1333 \mathrm{~B}$ & $0.1125 \mathrm{~B}$ & \\
\hline
\end{tabular}


Table 7. Measurements of time, germinability, velocity, uniformity and synchrony of germination of pyrenes of Schefflera morototoni (Aubl.) Maguire, Steyerm \& Frodin belonging to different samples and measured from three sample sizes (S.S.) ${ }^{1}$. 1: Sample with low physiological quality; 2: Sample with medium physiological quality; 3: Sample with high physiological quality.

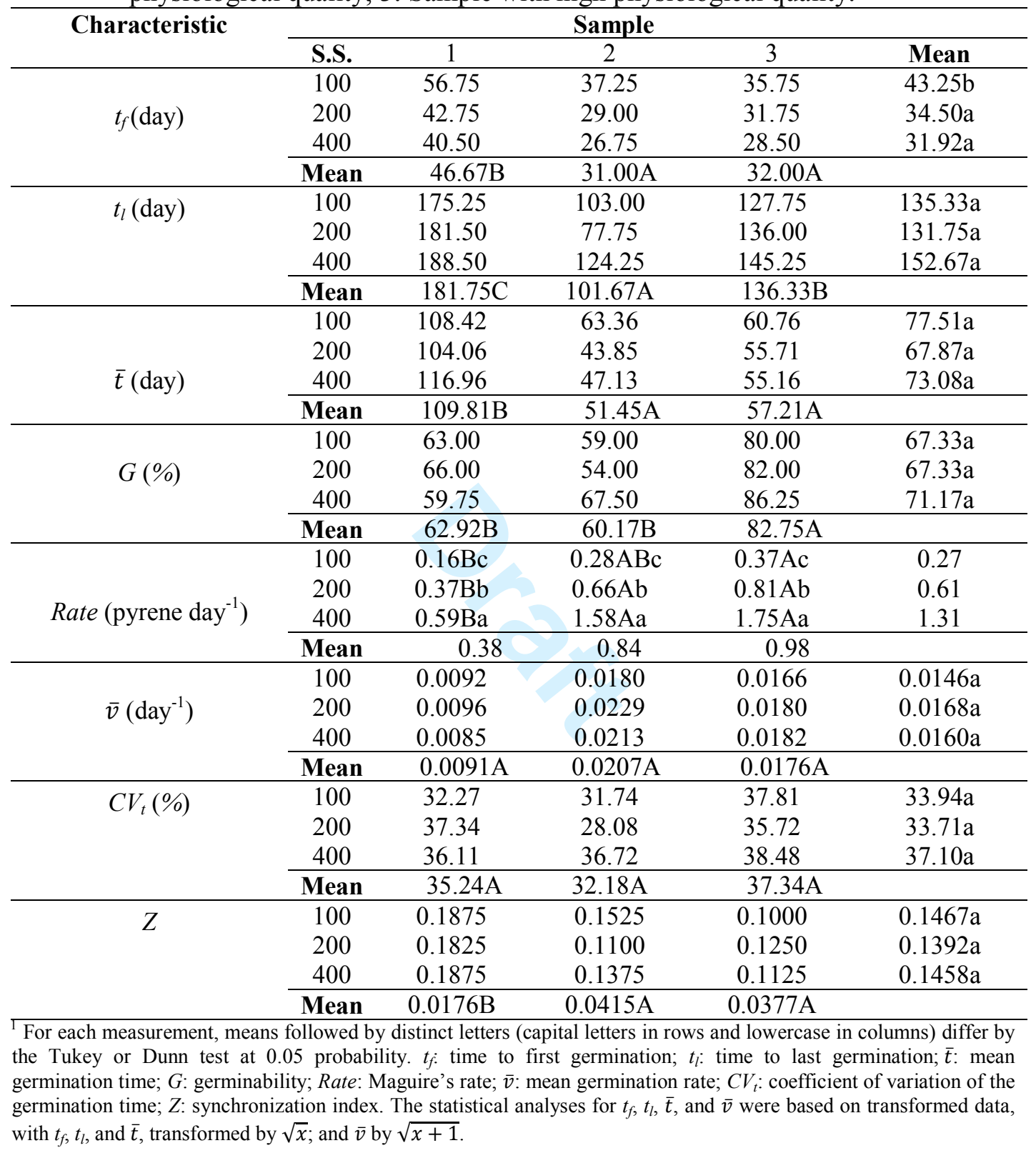


Figure 1: Frequency of sensitivity cases to differences in sample size and physiological quality (factorial effect), and sample size or physiological quality (main effects). $t_{f}$ : time to first germination; $t_{l}$ : time to last germination; $\bar{t}$ : mean germination time; $G$ : germinability; Rate: Maguire's rate; $\bar{v}$ : mean germination rate; $C V_{t}$ : coefficient of variation of the germination time; $Z$ : synchronization index. 


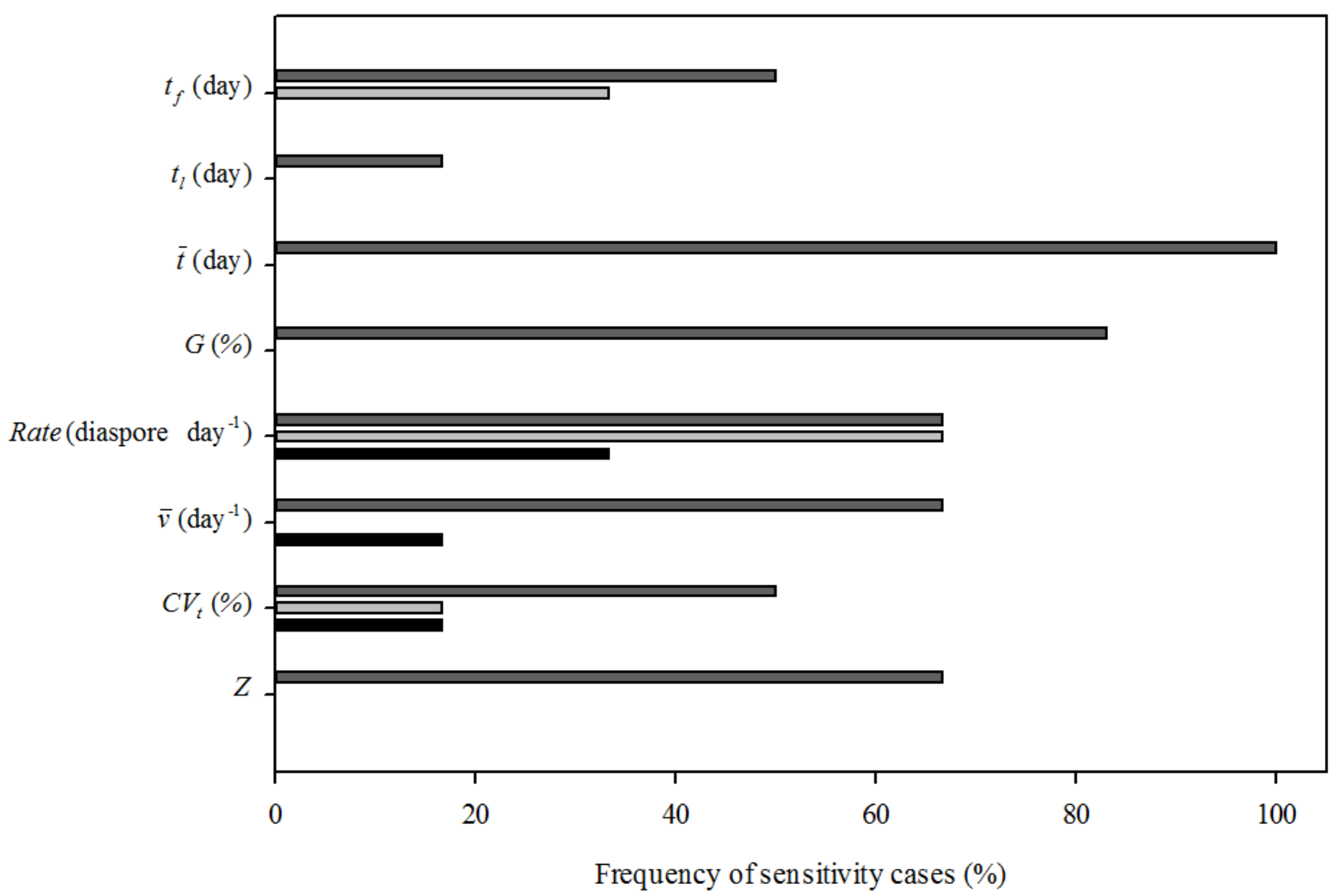

Sensitivity to differences in sample size and physiological quality - Factorial Effect $\square$ Sensitivity to differences in sample size - Main Effect

Sensitivity to differences in physiological quality - Main Effect https://mc06.manuscriptcentral.com/botany-pubs 